\title{
Perceptions of the mentally ill Irish population during the nineteenth and early twentieth centuries
}

Michael Robinson

\section{(2) OpenEdition \\ 1 Journals}

\section{Electronic version}

URL: http://journals.openedition.org/etudesirlandaises/5306

DOI: $10.4000 /$ etudesirlandaises.5306

ISSN: 2259-8863

\section{Publisher}

Presses universitaires de Caen

\section{Printed version}

Date of publication: 29 November 2017

Number of pages: $59-71$

ISBN: 978-2-7535-7388-8

ISSN: 0183-973X

\section{Electronic reference}

Michael Robinson, « Perceptions of the mentally ill Irish population during the nineteenth and early twentieth centuries », Études irlandaises [Online], 42-2 | 2017, Online since 29 November 2017,

connection on 14 September 2019. URL : http://journals.openedition.org/etudesirlandaises/5306 ; DOI : 10.4000/etudesirlandaises.5306 


\title{
Perceptions of the Mentally Ill Irish Population During the Nineteenth and Early Twentieth Centuries
}

\author{
Michael Robinson \\ University of Liverpool
}

\begin{abstract}
Analyses of British discriminatory perceptions of the Irish population during the nineteenth and twentieth centuries are well versed in the historiography. Previous works have demonstrated that the Irish migrant population were perceived to be drunkards, thieves, aggressive and unhygienic. Yet, in comparison, psychiatric discourse has received far less attention from historians. This article is an attempt to redress this imbalance. In addition to demonstrating that mental ill-health was an ingredient of anti-Irish perceptions, it will also suggest that descriptions of the mentally unstable Irishman also constituted a "pro-union psychiatry". In an attempt to delegitimize Irish political positions and demands for self-rule, Britons portrayed the Irish as childlike, volatile and mentally unwell and, therefore, incapable of governing themselves and legitimising the Union. The strength of this anti-Irish psychiatry survived the First World War and would persist throughout the inter-war period. This research aims to contribute towards the historiography of anti-Irish perceptions and extend burgeoning research which has explored the intrinsic relationship between imperialism and psychiatric diagnoses.
\end{abstract}

Keywords: Anti-Irish Racism, Psychiatry, Irish Migration, Shell-Shock.

\section{Résumé}

Les analyses des perceptions discriminatoires des Britanniques envers la population irlandaise au cours des XIX et XX siècles sont bien ancrées dans l'historiographie. De précédents travaux ont démontré que les membres de la population migrante irlandaise étaient perçus comme des ivrognes et des voleurs, agressifs et sales. Pourtant, en comparaison, le discours psychiatrique a reçu beaucoup moins d'attention de la part des historiens. Cet article tente de remédier à ce déséquilibre. En plus de démontrer que le trouble mental était un des éléments des sentiments anti-irlandais, il suggérera également que les descriptions de l'Irlandais comme étant mentalement instable constituaient aussi une "psychiatrie en faveur de l'Union". Afin de délégitimer les positions politiques irlandaises et les revendications d'autonomie législative, les Britanniques représentaient les Irlandais comme étant infantiles, instables et mentalement déséquilibrés et par conséquent incapables de se gouverner euxmêmes, légitimant ainsi l'Union. La force de cette psychiatrie anti-irlandaise survécut à la Première Guerre mondiale et persista durant l'Entre-deux-guerres. Cette recherche a pour but de contribuer à l'historiographie des perceptions anti-irlandaises et d'étendre la recherche émergente qui explore les relations intrinsèques entre l'impérialisme et les diagnostics psychiatriques.

Mots clés : Racisme anti-irlandais, Psychiatrie, Migration irlandaise, Obusite. 
Analyses of British discriminatory perceptions of the Irish population during the nineteenth and twentieth centuries are well versed in the historiography. In particular, the Irish were perceived to be drunkards, thieves, aggressive and unhygienic. Yet, in comparison, psychiatric discourse has received far less attention from historians. This article is an attempt to redress this imbalance. In addition to demonstrating that mental ill-health was an ingredient of anti-Irish perceptions, it will also suggest that descriptions of the mentally unstable Irishman also constituted a "pro-union psychiatry" where, in an attempt to delegitimise Irish political positions and demands for self-rule, Britons portrayed the Irish as childlike, volatile and mentally unwell. The strength of anti-Irish psychiatry survived the First World War. Thus, this research aims to contribute towards the historiography of anti-Irish perceptions and extend burgeoning research which has explored the intrinsic relationship between imperialism and psychiatric diagnoses ${ }^{1}$.

\section{Anti-Irish Racism before the First World War}

By 1900 , perceptions of the Irish were a consequence of firmly established ideas of race. ${ }^{2}$ This would impact upon, and be influenced by, the influx of Irish migrants who arrived in Britain in the aftermath of the Irish Famine, 18451852. Whilst the 1841 census records that over 400,000 Irish-born were living in Britain ${ }^{3}$, this number had increased to 781,119 in the census of $1881^{4}$. Whilst recognising the long history and complex nature of anti-Irish views, this escalation in the migrant population offers an integral explanation as to why anti-Irishness was at its most vicious in Victorian society 5 .

Due to police discrimination and judicial bias, the Irish were overrepresented in Victorian criminal statistics, being especially prone to arrests as a result of drunkenness, theft, prostitution, and fighting ${ }^{6}$. Indeed, Irish criminality was overwhelmingly concentrated in these less-serious or petty categories and was not particularly associated with graver crimes such as murder. However, when enga-

1. Erik Linstrum, Ruling Minds: Psychology in the British Empire, Harvard, Harvard University Press, 2016.

2. Rather than simply denoting skin colour, as its meaning represents in the twenty-first century, the definition of "race" and racial distinctions were divided along physical features, language and conduct in the nineteenth century. See Santanu Das (ed.), Race, Empire and First World War Writing, Cambridge, Cambridge University Press, 2011, p. 12; L.P. Curtis, Anglo-Saxons and Celts: A Study of Anti-Irish Prejudice in Britain, Bridgeport, New York University Press, 1968, p. 18 and p. 48.

3. Donald M. MacRaild, Irish Migrants in Britain, 1750-1922, Basingstoke, Palgrave Macmillas, 1999, p. 156.

4. John Archer Jackson, The Irish in Britain, London, Routledge and Kegan Paul, 1963, p. 10-11.

5. D.M. MacRaild, Irish Migrants in Britain, op. cit., p. 156.

6. Roger Swift, "Crime and the Irish in Nineteenth century Britain, 1871-1921", in Roger Swift and Sheridan Gilley (eds.), The Irish in Britain, 1815-1939, London, Pinter Publichers, 1989, p. 165-78; Alan O’Day, "Varieties of anti-Irish behaviour, 1846-1922", in P. Panayi (eds.), Racial Violence in Britain in the Nineteenth and twentieth centuries, London, Leicester University Press, 1996, p. 30-31; F. Finnegan, Poverty And Prejudice: A Study of Irish Immigrants in York, 1840-75, Cork, Cork University Press, 1982, p. 153. 
ging with these statistics, it is important to remember that Irish migrants largely settled in industrial areas which were already overcrowded, dirty, and deprived before their arrival en masse from the $1830 \mathrm{~s}^{7}$. It was, therefore, poverty, rather than ethnicity, which explained Irish exceptionalism with regards to prostitution, alcoholism, criminality, and public order offences ${ }^{8}$. Nevertheless, these descriptions became fundamental ingredients within anti-Irish racism, hardening existing anti-Irish prejudices which purported a predisposition to brutality and savagery?

Irish migrants, settling in huge numbers in over-crowded and poverty-ridden areas, were also associated with importing disease and mental illness ${ }^{10}$. For example, in 1886 and 1870 local press reports in Lancashire discussed the "Irish problem", a widely-held assumption that Irish authorities exported its mentallyill population to the North-West of England in order to pass the responsibility of "ould Ireland's demented children" to regional asylums ${ }^{11}$. An analysis of nineteenth-century British asylum casebooks demonstrates anti-Irish sentiments were evident as Irish patients became stigmatised ${ }^{12}$. "Bad Irish character" was referenced with Irish patients being portrayed as volatile, aggressive, criminal, illdisciplined and in need of strict management from asylum staff ${ }^{13}$. In 1883, the Commissioners in Lunacy Report wrote that Rainhill Asylum in Merseyside had "an excessive proportion of bad cases; many of them natives of Ireland and turbulent in disposition ${ }^{14 "}$. One Irish patient in Rainhill Asylum was described as being "quite demented and resembles more a monkey than a human being" in $1873^{15}$.

7. Catherine Cox, Hilary Marland and Sarah York, "Itineraries and Experiences of Insanity: Irish migration and the management of mental illness in nineteenth Century Lancashire", in Catherine Cox, Hilary Marland and Sarah York (eds.), Migration, Health and Ethnicity in the Modern World, Basingstoke, Palgrave Macmillan, 2013, p. 39.

8. Jacqueline Turton, "Mayhew's Irish: the Irish poor in mid nineteenth-century London”, in Roger Swift and Sheridan Gilley (eds.), The Irish in Victorian Britain: The Local Dimension, Dublin, Four Courts Press, 1999, p. 146; Walter Ralls, "The Papal Aggression of 1850: A study in Victorian Anti-Catholicism”, Church History, vol. 43 no. 2, 1974, p. 244.

9. D.M. MacRaild, Irish Migrants in Britain, 1750-1922, op. cit., p. 164; Swift, "Crime and the Irish in nineteenth century Britain, 1871-1921", op. cit., p. 177; Mark Finnane, Insanity and the Insane in Post-Famine Ireland, London, Croom Helm, 1981, p. 74; Liz Curtis, Nothing But The Same old Story: the roots of anti-Irish racism, London, Information on Ireland, 1984, p. 10; John Harrington, The English Traveller in Ireland: Accounts of Ireland and the Irish through five centuries, Dublin, Wolfhound Press, 1991, p. 65 and p. 88-89; Andrew Hadfield and John McVeagh, Strangers to that Land: British Perceptions of Ireland from the Reformation to the Famine, Gerrards Cross, Colin Smythe, 1994, p. 46.

10. C. Cox, Marland and York, "Itineraries and Experiences of Insanity", op. cit., p. 40 and p. 55.

11. Bernard Melling, "Building a Lunatic Asylum: 'A Question of Beer, Milk and the Irish", in Thomas Knowles and Serena Trowbridge (eds.), Insanity and the Lunatic Asylum in the Nineteenth Century, London, Routledge, 2015, p. 60-63.

12. Catherine Cox, Hillary Marland and Sarah York, "Emaciated, Exhausted and Excited: The Bodies and Minds of the Irish in Late Nineteenth-Century Lancashire Asylums", Journal of Social History, vol. 46, no. 2, 2012, p. 517.

13. Ibid., p. 512.

14. C. Cox, H. Marland, S. York, "Itineraries and Experiences of Insanity", op. cit., p. 51.

15. C. Cox, H. Marland, S. York, “Emaciated, Exhausted, and Excited”, op. cit., p. 515. 
These "scientific" theories of the simian Irish repeated the widely-held belief that the Irish might be the ever-elusive missing link between humans and chimpanzees. Connotations of the Irish being "ape-like" became a notorious racist cliché in Victorian Britain repeated by historians and travel writers ${ }^{16}$. Opinions of Irish emotionality, immaturity, mental fragility, and liability to insanity became widespread in British society to the extent that they influenced the medical opinion of asylum staff. As with suppositions that the Irish were prone to public disorder and criminality, however, theories regarding mental disposition were seemingly verified by evidence.

\section{The Irish in the Asylum, 1820-1913}

Despite the huge increase in the provision of Irish asylums during the nineteenth century, applications for asylum care continued to rise ${ }^{17}$. The dramatic build-up in the asylum population in Ireland is demonstrated in the following table.

\begin{tabular}{|c|c|}
\hline Year & Asylum Population \\
\hline 1851 & 2,802 \\
\hline 1861 & 4,623 \\
\hline 1871 & 7,831 \\
\hline 1914 & 24,815 \\
\hline
\end{tabular}

Table 1: Asylum Population, 1851-191418

As a result of the dramatic decrease in the Irish population, the annual report produced by the inspectorate of lunatic asylums in the country stated in 1906:

Lunacy is extraordinarily prevalent in Ireland. In the lunacy inspectors' office in Dublin castle, I was given the last comparison they had published of the insanity rates in England and Wales, Scotland and Ireland. English and Welsh insanity per 10,000 people was 40.8; Scottish, 45.4; Irish, 56.2. The Irish rate for 1916 showed an increase to $57.1^{19}$.

Indeed in 1909, Irish Parliamentary Party journalist, R. Barry O’Brien, lamented that "the three scourges which afflict Ireland... Emigration, Tubercu-

16. David Day, Conquest: How Societies Overwhelm Others, Oxford, Oxford University Press, 2008, p. 84; L.P. Curtis, Anglo-Saxons and Celts, op. cit., p. 84.

17. Pauline Prior, "Overseeing the Irish Asylums: Inspectorate in Lunacy, 1845-1921", in Pauline Prior (ed.), Asylums, Mental Health Care and the Irish, 1800-2010, Dublin, Irish Academic Press, 2012, p. 222-4.

18. Table adapted from ibid., p. 227.

19. Ruth Russell, What's the Matter With Ireland?, New York, 1920, p. 40-41. 
losis and Lunacy ${ }^{20}$ ". The increasing numbers of people certified as insane in the country seemingly offered conclusive evidence for the suggestion that the Irish race was susceptible to mental illness ${ }^{21}$.

Irish-born patients also constituted the most prominent ethnic identity after the native-born population in English asylums ${ }^{22}$. For example, at the Rainhill, Prestwich, Lancaster and Whittingham asylums, the Irish population constituted around ten per cent of the patient population with the next highest demographic, Scottish-born patients, totalling just over one per cent ${ }^{23}$. Occurring at the same time as widespread concern regarding high asylum numbers in Ireland and unfavourable descriptions of the Irish migrant population in British towns and cities $^{24}$, large Irish populations under treatment in British asylums was attributed by the local press and medical officials to a national predisposition for institutionalisation $^{25}$.

Over the past thirty years, academics have re-visited the issue in an attempt to explain the augmentation in Irish lunacy figures placing a "greater emphasis on the social and cultural forces that inflect diagnosis and perceptions of illnesses ${ }^{26 "}$. Historians have theorised that the asylum becoming a place of refuge during the famine years $^{27}$, the increase in people living beyond the age of sixty-five ${ }^{28}$, the asylum not being feared in the same way as the workhouse $e^{29}$, and abuses in the highly-flawed Dangerous Lunacy legislation of 1857 were contributory factors to explain the inflation of Irish patients ${ }^{30}$.

20. Elizabeth Malcolm, "Ireland's crowded madhouses: the Institutional Confinement of the Insane in Nineteenth- and Twentieth-Century Ireland", in Roy Porter and David Wright (eds.), The Confinement of the Insane: International Perspectives, 1800-1965, Cambridge, Cambridge University Press, 2003, p. 326.

21. Ibid., p. 327.

22. C. Cox, Marland and York, "Itineraries and Experiences of Insanity", op. cit., p. 36; E. Malcolm, "A most miserable looking object”, op. cit., p. 121.

23. Liverpool Record Office (M 614/RAI 4), Report of the Medical Superintendent, Lancaster Asylum, 1920, p. 33; Report of the Medical Superintendent, Rainhill Asylum, 1913, p. 28; Report of the Medical Superintendent, Prestwich Asylum, p. 106; Report of the Medical Superintendent, Whittingham Asylum, 1919, p. 148.

24. C. Cox, Marland and York, "Itineraries and Experiences of Insanity", op. cit., p. 55.

25. Ibid., p. 47.

26. Ian Miller, "Review of Irish Insanity, 1800-2000", Irish Studies Review, vol. 23 no. 4, 2015, p. 503-504.

27. Damian Brennan, "A Theoretical Exploration of Institution-based Mental Health Care in Ireland", in Pauline Prior (ed.), Asylums, Mental Health Care and the Irish, 1800-2010, op. cit., p. 289-292.

28. Finnane, Insanity and the Insane in Post-Famine Ireland, op. cit., p. 143.

29. Ibid., p. 109-110; Elizabeth Malcolm, "The Institutional confinement of the insane in nineteenth- and twentieth-century Ireland", in Roy Porter and David Wright (eds), The Confinement of the Insane: International Perspectives, 1800-1965, op. cit., p. 323; Brennan, Irish Insanity, Routledge Advances in Sociology, 2015, p. 81; Elizabeth Malcolm, "The House of Strident Shadows': the asylum, the family, and emigration in post-famine rural Ireland”, in Greta Jones and Elizabeth Malcolm (eds.), Medicine and Disease and the state in Ireland, 1650-1940, Cork, Cork University Press, 1999, p. 186.

30. Pauline Prior, "Mental Health Law on the Island of Ireland, 1800-2010", in Pauline Prior (ed.), Asylums, Mental Health Care and the Irish 1800-2010, op. cit., 2012, p. 320. 
With regards to Irish-born patients in British asylums, it has, again, been argued that it was the poverty Irish migrants faced during the period which often caused their admittance into an asylum rather than any inherent racial characteristics $^{31}$. The loss of contact with friends and family that accompanied migrant life was another potential explanation for these institutional tendencies ${ }^{32}$. Historians have also theorised that doctors, largely Protestant, educated, and middle-class men, were influenced by popular assumptions of the working-class and Catholic Irish which ensured many Irish inmates were retained within the asylum longer than the English-born contingent ${ }^{33}$.

Despite the absence of any empirical data, a similar narrative reporting an Irish predisposition to mental illness was prevalent regarding "functional nervous diseases" such as neurasthenia. Some medical texts stated that practitioners often dealt with a neurasthenic temperament in its most acute stage rather than a treatable ailment. Arguments of a "neurotic temperament" were formulated, and hereditary, racial and national health had a fundamental role in its explanation ${ }^{34}$. Medical textbooks designated race, alongside hereditary, gender, and age, as a contributory factor to explain the existence of such a disorder ${ }^{35}$. Shortly before the commencement of the First World War, one article in The Lancet decreed that the nationality of a patient diagnosed with neurasthenia should be considered before recommendation for treatment ${ }^{36}$. The ailments were presented by the medical establishment as very un-English disorders ${ }^{37}$. Perceptions of functional nervous disorders were offered by high-profile British medical officers during the Victorian and Edwardian as particularly prevalent in countries which apparently accommodated simpler and more impulsive populations $s^{38}$. As George Mosse points out, "Hysteria and nervousness became racial characteristics ${ }^{39 "}$.

31. Elizabeth Malcolm, "A most miserable looking object - The Irish in English Asylums", 1851-1901: Migration, poverty and prejudice", in John Belchem and Klaus Tenfelde (eds.), Irish and Polish Migration in Comparative Perspective, Essen, Klartext Verlag, 2003, p. 125-126; John Fox, "Irish Immigrants, Pauperism and Insanity in 1854 Massachusetts", Social Science History, vol. 15 no. 3, 1991, p. 331.

32. E. Malcolm, "A most miserable looking object", op. cit., p. 131; Cox, Marland and York, "Itineraries and Experiences of Insanity", op. cit., p. 55.

33. E. Malcolm, "A most miserable looking project", op. cit., p. 129-131.

34. Tracey Loughran, "Hysteria and neurasthenia in pre-1914 British medical discourse and in histories of shellshock", History of Psychiatry, vol. 19 no. 73, 2008, p. 38-39.

35. Tracey Loughran, "Shell-Shock in First World War Britain: An intellectual and Medical History, 1860-1920", PhD Thesis, Queen Mary, University of London, 2006, p. 61.

36. J.S.R. Russell, “Treatment of Neurasthenia”, Lancet, vol. 2, 1913, p. 1453-56.

37. Loughran, "Hysteria and Neurasthenia in Pre-1914 British Medical Discourse and in Histories of Shellshock", op. cit., p. 40.

38. Andrew Scull, Madness: A Very Short Introduction, Oxford, Oxford University Press, 2011, p. 61-62.

39. George Mosse, "Shell-Shock as a social disease", Journal of Contemporary History, vol. 35 no. 1, 2000, p. 103. 
Connotations of the childlike, volatile, and emotionally unsuitable Irish person were long-standing in British thought ${ }^{40}$. In 1852, The Edinburgh Review commented: "That strange mixture of strong passion and playfulness... was so prominent a part of Irish character... distinguished by a capricious instability of national temper, which time has but little modified." This description would persist throughout and beyond the nineteenth century ${ }^{41 .}$ Even seemingly placid descriptions could belittle the Irish. Descriptions of being creative, emotional, playful, and zealous also accompanied depictions of children ${ }^{42}$. The need for paternalistic relations with the Irish was emphasised by Robert Knox, arguably the most high-profile promoter of racial determinism ${ }^{43}$. The Irish were thus presented as immature and in need of discipline by others more sufficiently capable than themselves ${ }^{44}$.

This connotation of being immature and childlike is worth highlighting. Mental health historians have continuously noted the intrinsic relationship between childhood and insanity in medical and political discourse during the nineteenth and early-twentieth centuries. The mentally ill were often treated and described as children needing constant supervision from a mature parental figure $^{45}$. In an article for the Journal of Mental Science, published in 1894, Dr Thomas Draper, the Resident Medical Superintendent of Enniscorthy District Asylum, further emphasised Irish mental instability:

Temperament and racial characteristics have, no doubt, much to do with susceptibility to mental derangement, and here the Irish are at a disadvantage. An excitable brain is an easily disturbed brain; and the quick witted, passionate, versatile and vivacious Celt has, for those qualities which made him so charming, too often to pay the price of instability ${ }^{46}$.

Perceptions of Irish immaturity, emotionality, and mental instability undermined the Irishman's capability for self-government and therefore legitimised English policy and control in Ireland ${ }^{47}$.

40. Arnold also prominently voiced the view that the Irish were incapable of self-governance in On the Study of Celtic Literature, London, David Nutt, 1910; L.P. Curtis, Apes and Angels: the Irishman in Victorian Caricature, Smithsonian Institution Press, 1971, p. 18; Harrington, The English Traveller in Ireland, op. cit., p. 265.

41. L.P. Curtis, Anglo Saxons and Celts, op. cit., p. 53-55.

42. [http://www.victorianweb.org/history/race/Racism.html].

43. Edward Lengel, The Irish Through British Eyes: Perceptions of Ireland in the Famine Era, London, Praeger, 2002, p. 131.

44. Ibid.

45. Diana Louis, "Peculiar Institutions: Representations of Nineteenth-Century Black Women's Madness and Confinement in Slavery and Asylums", unpublished PhD thesis, Emory University, 2014, p. 113.

46. An edited copy of On The Alleged Increase of Insanity in Ireland, by Dr Thomas Draper, Resident Medical Superintendent, Enniscorthy District Asylum, 1894, "Voices of Doctors and Officials", in Pauline Prior (ed.), Asylums, Mental Health Care and the Irish: Historical studies 1800-2010, op. cit., p. 282.

47. L.P. Curtis, Anglo-Saxons and Celts, op. cit., p. 54-55. 
The political influence on this kind of psychiatric discourse has recently been explored in slave narratives. During the mid-nineteenth century, freed slaves in the United States of America were believed to be prone to insanity on account that they were psychologically unsuited and unprepared for liberty and freedom. Diana Louis terms this discourse as being part of a "pro-slavery psychiatry ${ }^{48}$ ". Similar aspersions were cast upon the Irish as a result of "pro-Union psychiatry". For example, one critic argued the Irish were unsuitable to have a say in their own government owing to their "fierce passions" of which one unenviable trait was "the unreasonableness of children ${ }^{49}$ ". In the aftermath of the United Irish rebellion, on 6 June 1798, the Morning Chronicle stated "the minds of the insurgents are so diseased and so infatuated". Those involved in the rebellion were depicted not as staunch rebels ideologically opposed to British rule but as momentarily mentally ill ${ }^{50}$.

Such a concept reflected a firmly-established notion of the relationship between Britain and Ireland: as a physician and allegorical patient. Fenian activities in the 1860s allowed the British press to repeat the supposed mental instability of the Irish agitators. The Daily Telegraph described "a feeling that Ireland is inflicted with an incurable disease... we may use the strait-waistcoat for her mad fits". The prognosis for recovery was also poor: "We can have no certain hope of seeing her one day clothed and in her right mind." Such associations were also evident in a satirical cartoon published in the aftermath of the Fenian Clerkenwell Bombing in 1867 where the intervention of a paternal British physician, Dr John Bull, ensured Paddy was no longer a danger to himself or others by admitting him into an asylum ${ }^{51}$.

The Land War of 1879-81 again prompted widespread press depictions of the mental and moral sickness of the Irish people where a "strait waistcoat" was required for the good of Ireland and the British Empire ${ }^{52}$. Indeed, even constitutional nationalists could equate more radical nationalists with the Irish propensity to mental illness. For example, Denis Kilbride, an MP for the Irish Parliamentary Party, replied to Sinn Féin supporting agitators during a political address by stating: "[T] here were so many young men in the asylums in Ireland and so many damned lunatics outside ${ }^{53}$."

48. Louis, "Peculiar Institutions", op. cit., p. 77-118.

49. Steven Fielding, Class and Ethnicity: Irish Catholics in England, 1880-1939, London, Open University Press, 1993, p. 9.

50. Michael Di Nie, The Eternal Paddy: Irish Identity and the British Press, 1798-1882, London, University of Wisconsin Press, 2004, p. 59.

51. Ibid., p.165.

52. Ibid., p. 175 and p. 215.

53. Paul Redmond, "Denis Kilbride M.P. 1848-1924, unpublished MA thesis, University of Maynooth, 2003, p. 318. 
From the French Revolution onwards, "revolutionary insanity" gained legitimacy in medical discourse. These politically-motivated diagnoses became seamlessly interwoven into already-established derogatory views of the Irish ${ }^{54} \mathrm{Per}-$ ceptions of the emotional Irish race being susceptible to mental instability were thus widespread in Victorian and Edwardian England ${ }^{55}$. Indeed, Louis argues that one way in which "pro-slavery psychiatry" lingered was in the treatment of African-American soldiers with continued aspersions they were predisposed to breakdown lingering throughout the twentieth century ${ }^{56}$. A similar narrative is evident in Ireland with the treatment of the Irish Tommy at the Front ${ }^{57}$.

\section{图 The First World War and the Inter-War Period}

Like the Irish in civil society, the Irish Tommy was perceived by the military establishment to be innately aggressive, and therefore an ideal shock troop, yet careless, ill-disciplined, prone to criminality, and filthy ${ }^{58}$. In a repeat of nineteenth-century British discourse, a paternal relationship was advocated at the Front. Rowland Fielding, a battalion commander of the Connaught Rangers, wrote home to his wife stating: "Ireland will always be Ireland. It is a land of children with the bodies of men." Again, like children, he confided to his wife that Irish troops were mentally fragile who were "easily made happy" but, also, "easily depressed"9". The War Office Committee of Enquiry into Shell-Shock included the testimony of Major Pritchard Taylor, who was a member of the Royal Army Military Corps during the conflict, who stated during his testimony that the Irish were liable to breakdown in comparison to their British-born comrades $^{60}$. The committee's report thus concurred listing "racial characteristics" as a "general predisposing cause" of shell-shock ${ }^{61}$. Irish nervous casualties received

54. Ibid., p. 79; Martin Miller, "The Concept of Revolutionary Insanity in Russian History” in Angela Brintlinger and ilya Vinitsky (eds.), Madness and the Mad in Russian Culture, Toronto, University of Toronto Press, 2007, p. 105-106.

55. L.P. Curtis, Anglo Saxons and Celts, op. cit., p. 53-55.

56. Margaret Humphreys, Intensely Human: the Health of the Black Soldier in the American Civil War, Baltimore, John Hopkins University Press, 2008, p. 9 and p. 55-56; R.F. Jefferson, "Enabled Courage': Race, Disability, and Black World War II Veterans in Post-War America”, The Historian, vol. 65 no. 5, 2003, p. 1104; E. Dwyer, "Psychiatry and Race during World War II", Journal of Medicine and Allied Sciences, vol. 61 no. 2, 2006, p. 143.

57. Similarly, with regards to English soldiers, the non-officer class were believed to be less civilised than their officers ensuring that they were more likely to suffer from hysteria than the more respectable neurasthenia.

58. Joanna Bourke, "Irish Tommies: The Construction of a Martial Manhood, 1914-18", Ballàn 6, 1998, p. 1330; Nicholas Perry, "Maintaining Regimental Identity in the Great War: The Case of the Irish Infantry Regiments", Stand To 54, 1998, p. 5-11.; Terence Denman, "The Catholic Irish soldier in the First World War: The 'Racial Environment”, Irish Historical Studies, vol. 27, no. 108, 1991, p. 352-365.

59. J. Bourke, "Irish Tommies", op. cit., p. 20.

60. The Southborough Report, War Office COmmittee of Enquiry into "Shell Shock" (1922), Southborough Report, London, HMSO, p. 87.

61. Ibid., p. 96. 
more dismissive and punitive treatment at the Casualty Clearing Hospitals at the front owing to their nationality ${ }^{62}$. Such perceptions lingered into the post-war world impacting upon the disabled Great War veteran.

At a conference of Neurological Deputy Commissioners of Medical Services held at London Headquarters on 17 June 1921, it was stated that waiting lists for treatment amongst mentally ill Great War veterans in "South Ireland" far outweighed comparative regional figures in the rest of the United Kingdom ${ }^{63}$. Dr A. Baldie, a Ministry of Pensions neurological expert, attributed this difference to "a definitive Neurasthenic temperament that was prevalent amongst the South Irish". Another official attending the conference, Dr Wallace, asserted that it was "indisputable" that those subject to mental illness were more likely to enlist in Ireland $^{64}$. Previous research has already ably demonstrated that the lack of investment, treatment facilities and employment opportunities help to explain the inflated waiting-list figures in "South Ireland" 65 ". Indeed, the fact that waiting lists for medical treatment for all disabilities in "South Ireland", regardless of physical or psychiatric diagnosis, were similarly inflated demonstrates that socio-political and economic reasons had an impact on returning disabled veterans ${ }^{66}$.

In 1920, the National Federation of Discharged and Demobilised Sailors and Soldiers wrote to the office of the British Prime Minister asking him to intervene and improve the plight of the physically and mentally disabled Great War veteran in Ireland ${ }^{67}$. Whilst accepting that the letter effectively conveyed their desperate plight, the Ministry of Labour advised Lloyd George's office not to reply. The department explained "the trouble is due to a kink in the Irish brain". It was decreed that regardless of any British intervention, "it is not in our power, or for that matter, in the power of any department, or of the government as a whole to straighten out this kink $^{68}$ ". As has been demonstrated, such attitudes regarding a "kink in the Irish brain" were long established.

Psychiatric aspersions were not restricted to the British ex-serviceman. Following the Anglo-Irish Treaty of 1921, a continuation of conflict ensued in

62. Joanna Bourke, "Effeminacy, Ethnicity and the End of Trauma: The Sufferings of 'Shell-Shocked' Men in Great Britain and Ireland, 1914-39”, Journal of Contemporary History, Vol. 35, No. 1, Special Issue: ShellShock, Jan., 2000, p. 57-69. p. 62; Joanna Bourke, "Shell-Shock, Psychiatry and the Irish Soldier", Adrian Gregory and Senia Paseta (eds.) Ireland and the Great War: "A War To Unite Us All?", Manchester, Manchester University Press, 2002, p. 62.

63. NA (PIN 15/56), Memorandum on Conference of Neurological D.Cs.M.S. held at Headquarters, 17 June 1921, p. 7.

64. Ibid., p. 4.

65. J. Bourke, "Shell-Shock, psychiatry and the Irish Soldier during the First World War", op. cit., p. 155-171.

66. NA (PIN 15/56), Memorandum on Conference of Neurological D.Cs.M.S. held at Headquarters, 17 June 1921, p. 4.

67. NA (LAB 2/855/ED5412/7/1921), National Federation of Discharged and Demobilised Sailors and Soldiers, Dublin, to David Lloyd George, 17 February 1920.

68. Ibid., Ministry of Labour to Prime Minister's Office, 24 March 1920. 
Ireland following a split in the Republican movement over the Anglo-Irish Treaty. Rejecting the compromised dominion status of the Free State, and the partition of Ireland, de Valera and anti-Treaty IRA units took up arms to fight against the Treaty but were ultimately defeated. Once again, political opposition was associated with mental illness with Punch magazine presenting Michael Collins and James Craig as mature farm holders discussing territorial boundaries but equating the anti-Treaty IRA to a mad bull threatening to compromise any constitutional settlement ${ }^{69}$.

This narrative returned with the next seismic event in the Irish political landscape: the election of Eamon de Valera’s Fianna Fáil party in 1932. Ministry of Pensions officials working in the Free State noted the "the possibility of grave developments hereafter" which could impact upon the Ministry of Pensions" running in the state. For example, potential retaliations by the IRA against Leopardstown Hospital were considered ${ }^{70}$. R.S. Oldham, the Resident Superintendent of the hospital, described the situation as one of "grave uncertainty and anxiety $^{71}$ ". As a result, plans for evacuating staff, patients, and confidential official documents to Britain were put in place should the situation deteriorate ${ }^{72}$.

In an attempt to defuse the situation, Oldham offered his services to the British government to act as an intermediary between de Valera and the British Government during this political impasse. A psychiatrist of Anglo-Irish stock, Oldham believed that he had a unique insight into the contrasting "mental outlook" of Britons and Irishmen. He was particularly considerate of de Valera's supposed state of mind: "I have the medial knowledge which I deem essential for dealing with the psychological problem presented by Mr. de Valera's mind ${ }^{73}$." This viewpoint was shared by the Foreign Secretary, Sir John Simon, who wrote to Ramsay Macdonald, Premier of the National Government, describing de Valera as "the exalted lunatic who is at the head of the Government in Dublin ${ }^{74}$. . Regardless, nothing came of Oldham's offer to act as an intermediary, but neither was there any Republican retribution aimed towards Leopardstown Hospital or the Ministry of Pensions ${ }^{75}$.

69. [http://Punch.photoshelter.com].

70. NA (MH 79/451), The Position of Leopardstown Hospital Dublin in the event of a crisis arising in the Irish Free State, 16 June 1932; G.C. Tryor to J.H. Thomas, Dominions Office, London, 21 June 1932.

71. NA (MH 79/451), RS Oldham, Leopardstown Park to Ministry of Pensions, Dublin, 17 July 1932.

72. Ibid., The Position of Leopardstown Hospital Dublin in the event of a crisis arising in the Irish Free State, 16 June 1932; G.C. Tryor to Dominions Office, London, 21 June 1932; "Confidential Note written by RS Oldham", 4 June 1932.

73. Ibid., R.S. Oldham, Leopardstown Park, to Ministry of Pensions, Dublin, 17 July 1932.

74. Paul M. Canning, "The Impact of Eamon De Valera: Domestic Causes of the Anglo-Irish Economic War", Albion: A Quarterly Journal Concerned with British Studies, Vol. 15, No. 3, Autumn, 1983, p. 179-205.

75. Although the economic trade war ensued between the two governments and lasted between 1932 and 1938; Kevin O'Rourke, "Burn Everything British but Their Coal: The Anglo-Irish Economic War of the 1930s", The Journal of Economic History, vol. 51 no. 2, 1991, p. 357-366. 
Once again, these theses reflected societal discourse. During the inter-war period, numerous literary depictions of fictional Irish characters displayed clear symptoms of a variety of mental illnesses. Memoirs, genealogical stud-books", and anthropologists, all emphasised such mental traits were hereditarily passed on between races and, as a result, characteristics mostly remained confined between certain peoples including the Irish $^{76}$. Popular novelist, George Birmingham, published A Lunatic at Large (1922) which repeated theories purporting a racial defect inherent amongst the Irish which explained the apparent prevalence of lunacy in Ireland ${ }^{77}$. Indeed, as Peter Barham argues: "race-based psychiatry" in Britain "held its own well into the twentieth century ${ }^{78 "}$ ". Perceptions of Irish mental instability was part of this medical discourse.

In addition to politically-motivated psychiatry in Ireland, perceptions of the unhygienic Irish migrant population lingered into the 1920s. British Government officials continued to hold that Ireland took advantage of the migrant passages to Britain by exporting her "indigent" and mentally-ill residents to clog up the English asylum. In 1924, a leading official at the British Treasury inferred:

It seems to me that so long as this country continues to give free admission to casual Irish labour every harvest time, and so enables the Free State both to relieve local unemployment, and to bring home English-paid wages, we have a good case for asking that they shall not take the opportunity to dump her lunatically minded population on to us in that way ${ }^{79}$.

Without a hint of irony, the same official conceded: "I have no information, but I suspect a good proportion of the civilian Irish lunatics in this country come from these annual migrants ${ }^{80}$." As has been demonstrated, this thesis was an uncomplicated continuation of prejudices evident in the previous century.

\section{Conclusion}

Politically-motivated diagnoses and anti-Irish perceptions of the migrant population collaborated to formulate aspersions purporting an Irish predisposition to mental illness. With these post-war examples in mind, this article would therefore dispute previous shell-shock historians who have argued that the First World War marked a "turning point" and a "major milestone" in the history of

76. L.P. Curtis, Anglo-Saxons and Celts, op. cit., p. 20-21 and p. 53-55.

77. E. Malcolm, "Ireland's Crowded Madhouses", op. cit., p. 315.

78. P. Barham, Forgotten Lunatics of the Great War, op. cit., p. 9.

79. Ibid., The Treasury, London, to Colonial Office, London, 17 September 1924.

80. NA (T 161/223), The Treasury, London, to Colonial Office, London, 17 September 1924. 
psychiatry ${ }^{81}$. Nevertheless, returning to the aforementioned empirical data which suggests an Irish predisposition to institutionalisation during the nineteenth century, the psychological impact of the Famine remains an omission in the historiography. On 26 September 1914, The Lancet, contended that the inflation of institutionalisation in Irish asylums was a "legacy of mental weakness dating from the sufferings of the famine years ${ }^{82}$ ". Whilst this article has stressed the collaboration of anti-migration discourse and politically-motivated diagnoses on psychiatric discourse, it also wishes to encourage further consideration of the psychological impact of the Famine by historians in the future ${ }^{83}$.

81. Anthony Babington, Shell-Shock: A History of the Changing Attitudes to War Neurosis, London, Leo Cooper, 1997, p. 122; Wendy Holden, Shell-Shock, London, Channel 4 Books, 1998, p. 137.

82. J. Bourke, "Effeminacy, ethnicity and the end of trauma", op. cit., p. 61.

83. Ian Miller, "Review of Irish Insanity, 1800-2000", Irish Studies Review, vol. 23 no. 4, 2015, p. 503-504. 